\title{
A FORMAÇÃO SETE LAGOAS (GRUPO BAMBUÍ) E AS VARIAÇÕES PALEOAMBIENTAIS NO FINAL DO PROTEROZÓICO
}

\author{
Lucieth Cruz Vieira \\ Orientador: Dr. Ricardo Ivan Ferreira da Trindade (IAG-USP) \\ 198 p. - Tese (Doutorado) - Defesa 19.10.2007
}

\begin{abstract}
RESUMO. 0 fim do Proterozóico foi caracterizado por pelo menos três importantes eventos glaciais (Sturtian, Marinoan, Gaskiers), rapidamente sucedidos por uma ampla sedimentação carbonática. Esses depósitos marcam mudanças climáticas importantes durante os períodos Criogeniano e Ediacarano, que provavelmente repercutiram na evolução da biosfera. Os carbonatos que capeiam os sedimentos glaciais em diversos continentes apresentam uma assinatura isotópica de carbono semelhante, tipicamente negativa, e uma série de estruturas sedimentares "anômalas", dentre as quais leques de cristais de aragonita. No entanto, as condições paleoambientais e os processos relacionados à geração de tal registro ainda apresentam controvérsias. Nesta tese, a Formação Sete Lagoas (base do Grupo Bambuí), depositada sobre os diamictitos do Grupo Macaúbas no Cráton do São Francisco, foi alvo de um estudo detalhado envolvendo sedimentologia, estratigrafia, geoquímica, geocronologia, isótopos estáveis e paleomagnetismo. Essa unidade contém uma espetacular ocorrência de leques de cristais (pseudomorfos) de aragonita. A Formação Sete Lagoas em sua área-tipo compreende uma espessa sucessão carbonática subdividida em duas seqüências transgressivas. A primeira seqüência repousa diretamente sobre o embasamento cristalino (que corresponde a uma superfície de erosão equivalente do registro glacial Macaúbas). No início da evolução da bacia, o relevo irregular do embasamento propiciou a instalação de ambientes restritos, onde a conexão com o mar era limitada. Nesse cenário, propõe-se que a precipitação dos carbonatos (e a formação dos leques de cristais de aragonita) logo após o degelo foi fortemente influenciada por atividade microbiana, com a geração de um gradiente redox logo abaixo da interface sedimento-água. Na zona redutora, o excesso de alcalinidade favoreceu a precipitação de calcita micrítica, enquanto na zona oxidante um forte gradiente sulfático favoreceu a precipitação de aragonita. Esse gradiente redox é refletido nas anomalias de $\mathrm{Ce}$, nos isótopos de Fe e na mineralogia magnética. Os níveis de cristais apresentam valores de $\delta^{56} \mathrm{Fe}<-0,3 \%$, associados a magnetita e hematita produzidas por bactérias dissimilatórias de ferro. Por outro lado, 0 micrito apresenta valores menos negativos $\left(\delta^{56} \mathrm{Fe}>-0,2 \% \circ\right)$, associados a sulfetos de ferro formados a partir da atividade de bactérias sulfato-redutoras. As razões isotópicas de carbono para esses depósitos refletem essa assinatura biogênica, com valores de $\delta^{13} \mathrm{C}$ em torno de $-4,5 \%$. Com 0 avanço da transgressão e 0 estabelecimento da conexão marinha, a deposição passou a ser influenciada por tempestade e maré, e os valores $\delta^{13} \mathrm{C}$ representam a assinatura normal dos oceanos em torno de $0 \%$. Uma datação direta da base da seqüência carbonática Sete Lagoas indica que a deposição dessas rochas ocorreu há $740 \pm 22$ Ma atrás, permitindo correlacionar essa unidade aos depósitos pós-glaciais do Criogeniano (Sturtian). A segunda seqüência transgressiva afogou a rampa carbonática, depositando inicialmente carbonatos e argilitos em água profunda e depois calcários negros, ricos em matéria orgânica, depositados em ambiente costeiro e de rampa interna. Esses depósitos deram lugar a expressivas construções estromatolíticas correspondentes ao topo da unidade. 0 ambiente deposicional da segunda seqüência foi marcado por forte aporte de matéria orgânica, resultando em valores de $\delta^{13} \mathrm{C}$ bastante elevados nos carbonatos, atingindo até $+14 \%$. Esses resultados têm implicações importantes quanto à sincronia dos eventos glaciais Neoproterozóicos e o significado das assinaturas isotópicas e das estruturas sedimentares "anômalas" dos carbonatos de capa.
\end{abstract}

ABSTRACT. The end of Proterozoic Eon is punctuated by at least three glacial events (Sturtian, Marinoan, Gaskiers), followed by extensive carbonate sedimentation. These deposits mark significant environmental changes at Cryogenian and Ediacaran periods, which may have impacted the biosphere. Carbonates that cap glacial deposits in several continents typically show negative carbon isotope signatures and "anomalous" sedimentary structures, including aragonite crystal-fans. Environmental conditions controlling these ubiquitous deposits are still a matter of debate. Here, we present the results of a multi-approach study of the Sete Lagoas Formation (base of the Bambuí Group), which lies over glacial diamictites of the Macaúbas Group in the São Francisco Craton, including sedimentology, stratigraphy, geochemistry, stable isotopes, geochronology and paleomagnetism. This unit comprises a spectacular occurrence of (pseudomorphosed) aragonite crystal fans. In the study area, around the Sete Lagoas city (Minas Gerais State), the Sete Lagoas Formation comprises two carbonate-dominated transgressive successions. The first sequence lies directly over the Paleoproterozoic crystalline basement (an erosion surface equivalent to the Macaúbas glacial record). The first meters of carbonate sedimentation occurred in an epeiric platform, with limited connection to the ocean. We propose that the sedimentary record just after deglaciation, and the formation of aragonite crystal fans, was strongly influenced by a redox gradient close to the sediment-water interface as a result of intense microbial activity. Alkalinity excess in the reduction zone resulted in micritic calcite precipitation, whereas a strong sulphate gradient in the oxic zone favored aragonite precipitation. Changes in redox conditions are recorded by Ce anomalies, iron isotopes and magnetic mineralogy. Crystal layers show $\delta^{56} \mathrm{~F}$ values below $-0,3 \%$ associated to magnetite and hematite produced by iron dissimilatory bacteria, whereas micrite layers show less negative $\delta^{56} \mathrm{Fe}$ values above $-0,2 \%$ related to iron sulphides formed by sulfate-reducing bacteria. Negative carbon isotope ratios $\left(\delta^{13} \mathrm{C}\right.$ around $-4.5 \%$ ) are thought to reflect the biogenic signature. After further sea-level rise, ocean connection became more effective and the sedimentary and isotopic signals changed significantly. Deposition at the upper part of the first sequence was strongly influenced by storm and tide and the $\delta^{13} \mathrm{C}$ values shifted to $0 \%$. The direct dating of the first sequence, including crystal-bearing and storm influenced facies, by the Pb-Pb method yield an age of $740 \pm 22 \mathrm{Ma}$. This result implies that the Sete Lagoas Formation correlates with the Sturtian (Cryogenian) glacial events. The second transgressive sequence relates to the drowning of the carbonate ramp. It initiates with deposition of carbonate and pelites in deep water, changing upsection to organic matter-rich black carbonates deposited in coastal and inner ramp environments. Shallow-water stromatolitic building facies occur at the top of this sequence. The strong burial of organic matter marks the second sequence, which attains carbon isotope values as high as $+14 \%$ in the carbonate fraction. Our results have important implications on the synchrony of Neoproterozoic glacial events, and the significance of the isotopic record and the anomalous sedimentary structures found in cap carbonates. 